Hvolkova, L., Klement, L., Klementova, V., \& Kovalova, M. (2019). Barriers Hindering Innovations in Small and Medium-Sized Enterprises. Journal of Competitiveness, 11(2), 51-67. https://doi.org/10.7441/ joc. 2019.02 .04

\title{
BARRIERS HINDERING INNOVATIONS IN SMALL AND MEDIUM-SIZED ENTERPRISES
}

\author{
- Lenka Hvolkova, Ladislav Klement, Vladimira Klementova, \\ Marcela Kovalova
}

\begin{abstract}
Several research studies concur with the claim that the government, through its measures and active instruments, should influence the business environment, the innovation activity of enterprises and thus their competitiveness. It is the creation of motivating conditions and the elimination of some barriers that are the main area of government involvement in the innovative performance and competitiveness of the economy. The article analyzes the achievement of the goals set in the particular innovation policies of the Slovak Republic from 2008 to the present. The paper also identifies barriers which have been affecting innovation activities of small and medium-sized enterprises (SMEs) in Slovakia for the last six years. Secondary data from the research of the Slovak Innovation and Energy Agency are supported by data from empirical research performed in 2014 and repeated in 2017 in Slovakia. The authors use methods of analysis, comparison, deduction, as well as mathematical methods for processing the data collected. The representativeness of the samples was examined using Fisher's exact test. The research questions were answered by the non-parametric Friedman's test of variance analysis by ranks along with McNemar's test of marginal homogeneity among the barriers. The results confirmed that there was a significant difference among the innovation barriers to SMEs as well as in the importance of barriers to the particular size classes of respondents. Similarly, there was a shift in the rank of the most important barriers over the period of $2012-2017$.
\end{abstract}

Keywords: small and medium-sized enterprises, competitiveness, barriers of innovations, innovation policy JEL Classification: O30, O38, M10

Received: July, 2018

1st Revision: October, 2018

Accepted: April, 2019

\section{INTRODUCTION}

Globalization, economic changes, shortening of a product's lifecycle, enlarged production capabilities as well as competition in markets, the digitalization of industry (Industry 4.0) and fast changing customer preferences are characteristics of the current world economy. The Industry 4.0 phenomenon "focuses on the establishment of intelligent production processes. In the future, factories have to cope with the need of fast product development, flexible production as well as complex environments" (Einsiedler, 2013, p. 27). Enterprises must react by implement- 
ing organizational and technological innovations to set up a competitive advantage and maintain their competitiveness (Mosey et al., 2002). Being innovative brings advantages both to the enterprise and its surroundings, as "the innovative enterprise is the driving force in the creation of new management standards" (Zastempowski \& Przybylska, 2016, p. 43). Today, innovation is increasingly seen as the engine for the growth of enterprises and the larger economy as well, thus innovation should be managed at strategic level. Therefore, many governments apply policies focused on incentives for enterprises to stimulate the intensity of innovations within the economy. This place the elimination of innovation barriers at the center of innovation policy (Hölzl \& Janger, 2014; Hunady et al., 2017). The implementation of innovation policy, based on research and innovation strategies for smart specialization (RIS 3) and adapted to regional specifications, ranks among the most common and current interventions within the European Union (EU). "In order to fulfil the Europe 2020 strategic objectives on research and innovation, the EU regions must implement RIS3 and define a new transformation agenda capable of stimulating the competitive advantage and key knowledge assets of each region" (Rodríguez-Pose et al., 2014, p. 2).

The existence and intensity of innovation barriers in the economy influences its performance and competitiveness in the global market. Enterprises, especially small and medium-sized ones (SMEs), are very volatile, and the worsening of business conditions is reflected in their number and performance. As we are dealing with barriers to innovation, in Table 1 we present the share of innovative enterprises out of all enterprises in the Slovak Republic.

Tab. 1 - The share of innovative enterprises in Slovakia as of 2006. Source: Statistical Office of the SR, 2018

\begin{tabular}{|l|l|l|l|l|}
\hline & $\begin{array}{l}\text { Micro and small } \\
\text { enterprises }\end{array}$ & $\begin{array}{l}\text { Medium enter- } \\
\text { prises }\end{array}$ & Large enterprises & Total \\
\hline 2006 & $17.38 \%$ & $31.76 \%$ & $56.61 \%$ & $22.70 \%$ \\
\hline 2008 & $29.26 \%$ & $46.58 \%$ & $67.87 \%$ & $33.59 \%$ \\
\hline 2010 & $26.69 \%$ & $41.34 \%$ & $64.25 \%$ & $32.79 \%$ \\
\hline 2012 & $27.23 \%$ & $37.72 \%$ & $61.35 \%$ & $31.29 \%$ \\
\hline 2014 & $25.86 \%$ & $36.21 \%$ & $53.92 \%$ & $29.17 \%$ \\
\hline 2016 & $22.78 \%$ & $41.55 \%$ & $59.67 \%$ & $28.68 \%$ \\
\hline
\end{tabular}

The data in the table show that the highest share of innovative enterprises was among large enterprises. In the group of micro and small enterprises, the share of innovative companies grew to its maximum in 2008 (29.26\%), but then dropped to almost $23 \%$ in 2016 . The same trend can be observed in the group of medium and large enterprises. As SMEs in the Slovak Republic account for up to $99.9 \%$ (4.1 percentage points more than the average in EU countries) of all enterprises, it can be seen that the total share of innovative enterprises in Slovakia never exceeded $34 \%$, and in 2016 was only $28.68 \%$.

A comparison of the share of innovative enterprises within Visegrad countries is presented in the following figure. 


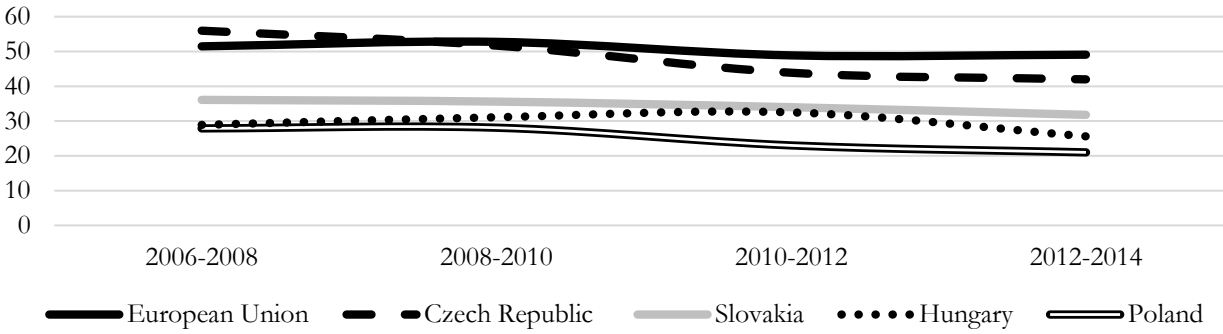

Fig. 1 - The share of innovative enterprises in Visegrad countries. Source: authors' own based on Eurostat data, 2018

In comparison to other Visegrad countries, Slovakia ranked second in terms of the share of innovative enterprises. The Czech Republic recorded the biggest fall during the observed period. Although the rate in other Visegrad countries was decreasing more slowly, their overall drop remained relatively large compared to Czech Republic. All Visegrad countries ranked below the EU average in the period of 2008 - 2014.

Innovation barriers dynamically change both over time as well as according to the type of enterprise activity (Hadjimanolis, 2003). Various authors present the following barriers to innovations as the most important for European SMEs: high costs of innovations, low-qualified and uninterested human resource departments, a corporate culture which does not support the innovative activities of employees, an administrative burden created by the state, ineffective information flows, and, finally, government policy (Demirbas et al., 2011). On the other hand, if enterprises are able to recognize the barriers within a short time, they are more likely to find solutions for eliminating them (Hueske et al., 2015). Therefore, the effort to identify the main barriers to innovation activities has become the subject of many researches.

A research conducted on a sample of small and medium-sized enterprises in Poland in 2012 and 2013 demonstrated that the most significant barrier to the innovativeness of enterprises was that they were operating in a sector which does not require any innovation (41\%). Other important reasons that may hinder the innovative activities were also the small size of the company $(34.2$ $\%$ ), lack of capital (32.1\%) and absence of pressure from clients (19.9\%) (Sieradzka, 2014).

The Czech Statistical Office conducted a questionnaire survey in 2018 with the sample of more than 5,600 Czech enterprises which was focused on monitoring innovation activities performed in the years 2014-2016 (Czech Statistical Office, 2018). From the total number of enterprises, only $46.3 \%$ indicated that they had engaged in innovation activities. The respondents had the possibility to identify the most significant barriers to innovation ranked on a four-point scale (high importance - no influence at all). According to the results, there was no difference between the perception of innovation barriers among innovative and non-innovative enterprises; on the other hand, the non-innovative enterprises simply measured barriers with a lower intensity. The following factors were marked as the most important barriers to innovation: the lack of financial sources (53.1\% from innovative enterprises, $37.7 \%$ from non-innovative enterprises), lack of qualified employees (49.4\% or $29.1 \%$ ), low or uncertain return of investments due to 
the size of the market ( $46.7 \%$ or $30.8 \%$ ), and problems obtaining public support for innovation activities $(44.0 \%$ or $27.1 \%)$.

The European Commission also initiated an extensive research focused on the evaluation of the innovation activities which included more than 13,000 respondents from the $28 \mathrm{EU}$ member states in February 2016 (Innobarometer 2016 - EU business innovation trends, 2016). One field of the research can be potentially connected to innovation barriers, but in a more specific way, as the respondents that introduced innovative goods or services were asked to consider the commercialization of their company's innovative goods or services, and to determine what types of problems they had faced along with their respective importance. Almost two thirds of respondents $(65 \%)$ considered as the most important problem the fact that the market was dominated by established competitors; more than half of the respondents (58\%) marked the lack of financial resources; and for $57 \%$ there was also a problem with the cost or complexity of meeting regulations or standards in the commercialization process of innovative goods or services. The following table presents detailed data for the group of $28 \mathrm{EU}$ countries and Visegrad countries.

Tab. 2 - Problems of the commercialization of the innovative goods or services (\%). Source: Innobarometer 2016 - EU business innovation trends

\begin{tabular}{|l|c|c|c|c|c|}
\hline $\begin{array}{l}\text { Problems of the commercialization of the innovative } \\
\text { goods or services }\end{array}$ & EU 28 & CZ & HU & PL & SK \\
\hline lack of human resources & 49 & 70 & 65 & 65 & 56 \\
\hline lack of financial resources & 58 & 61 & 53 & 68 & 75 \\
\hline finding or using new technologies & 35 & 36 & 23 & 47 & 30 \\
\hline cost or complexity of meeting regulations or standards & 57 & 64 & 61 & 73 & 63 \\
\hline difficulties in maintaining intellectual property rights & 23 & 25 & 19 & 32 & 23 \\
\hline administrative or legal issues & 46 & 57 & 47 & 64 & 55 \\
\hline lack of marketing expertise & 41 & 43 & 41 & 57 & 50 \\
\hline market dominated by established competitors & 65 & 72 & 66 & 80 & 62 \\
\hline a low demand for innovative goods or services & 45 & 42 & 37 & 56 & 46 \\
\hline weak distribution channels & 38 & 36 & 40 & 46 & 37 \\
\hline
\end{tabular}

These results confirm that the enterprises within Visegrad countries mostly perceived the same problems with the commercialization of innovative goods or services as did all EU countries. The surveyed enterprises in Slovakia considered as the most important problems the lack of financial resources $(75 \%)$, cost or complexity of meeting the regulations or standards $(63 \%)$, and the market being dominated by established competitors (62\%).

The present article focuses on the identification of the most significant barriers to innovation in Slovak enterprises and also critically analyses the fulfilment of the goals set by the innovation policies of the Slovak Republic. On the basis of the primary and secondary data, a number of recommendations for the possible future development of innovation performance for Slovak enterprises is proposed. 


\section{LITERATURE REVIEW}

Innovation activities are often associated with uncertain amount of costs, uncertain return of invested money and risk for the company (Ceccagnoli, 2009). Regarding innovation activities, enterprises are under constant pressure, the pressure is even higher, because the results should appear as soon as possible and with a high level of success. However, if the company wants to achieve growth and obtain a suitable position on the market, it is the only way how to achieve it (Cainelli et al., 2006). If the company is not capable of introducing innovations on an ongoing basis, it risks that it will get behind other companies and the initiative will be taken over by other entities (Urbancová, 2013). The ability of performing successful innovation activities depends on the company "combining a range of capabilities, including capacity to access finance, understanding market needs, recruiting high-skilled staff and establishing effective interactions with other actors" (D’Este et al., 2012, p. 482). Innovative companies are usually forced to deal with most, if not all of these challenges. The innovation process involves many risks and uncertainties, companies face many difficulties and obstacles, both internal and external. Therefore, they must be aware of these barriers and manage them in the best possible way (Keizer et al., 2002).

The most common categorization of innovation barriers used by many authors is based on Piatier's division of internal and external barriers. This typology defines internal barriers as those originating inside the company that an enterprise can influence, and include issues relating to functional areas inside the company as financial resources, human resources or corporate culture. On the other hand, some barriers are partially or completely beyond the influence of the enterprise as they arise in the external environment. These innovation barriers usually appear when the company interacts with other actors on the market (e.g. competitors, customers, partners, government) (Hölzl \& Janger, 2014; Madrid-Guijarro et al., 2009). The following table summarizes the classification with some sub-categories of each major type (Hadjimanolis, 2003; Madrid-Guijarro et al., 2009).

Tab. 3 - External and internal barriers to innovation. Source: Hadjimanolis, (2003); and Madrid-Guijarro et al. (2009)

\begin{tabular}{|l|l|l|}
\hline $\begin{array}{l}\text { Barriers to } \\
\text { innovation }\end{array}$ & Internal & External \\
\hline $\begin{array}{l}\text { Hadjiman- } \\
\text { olis (2003) }\end{array}$ & $\begin{array}{l}\text { 1. People related } \\
\text { 2. Structure related }\end{array}$ & $\begin{array}{l}\text { 1. Market related } \\
\text { 2. Strategy related }\end{array}$ \\
\hline $\begin{array}{l}\text { Madrid- } \\
\text { Guijarro et } \\
\text { al. (2009) }\end{array}$ & $\begin{array}{l}\text { 3. Lack of financial resources } \\
\text { 3. Weak corporate financial position }\end{array}$ & $\begin{array}{l}\text { 1. Turbulent business environment } \\
\text { 2. Lack of external co-operation op- } \\
\text { portunities } \\
\text { 3. Lack of information }\end{array}$ \\
\hline
\end{tabular}


Other authors (D'Este et al., 2012) characterize two groups of innovation barriers - revealed barriers to innovation and deterring barriers. The revealed barriers originate from the engagement of companies in innovation activities as during the innovation process they become aware of the associated difficulties. Barriers that prevent enterprises from engaging in innovation activities are identified as the deterring barriers. On the base of the research, the authors have proved that there is a "non-linear relationship between the degree of engagement in innovation activities and perception of barriers in the case of cost and market barriers to innovation" (Hölzl \& Janger, 2014, p. 721). Therefore, the deterring barriers endanger mostly non-innovative companies trying to engage in innovation activities. On the other hand, the revealed barriers to innovation occur mostly in innovative companies as they learn more about the difficulties of innovation after they decide to innovate (Hölzl \& Janger, 2014).

Hadjimanolis (1999, in Beranová et al., 2015) categorize barriers to innovation in a different way and define three groups - barriers connected to a supply or a demand side and barriers connected to a general environment. First group of innovation barriers originates from the lack of material or financial resources; needs of customers and a limited size of market may cause the origin of demand-side barriers. In case of government regulations or anti-trust interventions, there occurs the third type of innovation barriers - those connected to a general environment.

Duarte et al. (2017) define four main types of barriers to innovation - economic factors, knowledge factors, market factors and reasons to innovate (Fig. 2).

\begin{tabular}{|l|}
\hline Economic factors \\
\hline - lack of funds within \\
the enterprise or \\
group \\
- lack of finance of \\
sources outside the \\
enterprise \\
-innovation costs too \\
high \\
\hline
\end{tabular}

\begin{tabular}{|l|}
\hline Knowledge factors \\
\hline - lack of qualified \\
personnel \\
- lack of information \\
on technology \\
- lack of information \\
on markets \\
- difficulty in finding \\
cooperation partners \\
for innovation \\
\end{tabular}

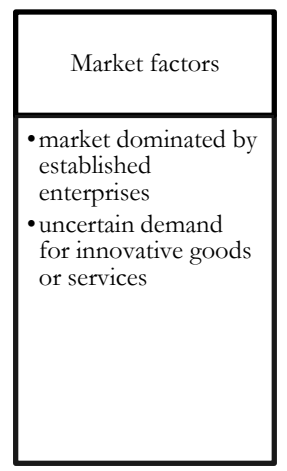
Reasons to innovate
- no need due to prior
innovations by the
enterprise
- no need becausse of
no demand for
innovation

Fig. 2 - Barriers to innovation. Source: Duarte et al. (2017)

SMEs usually face more problematic situations and factors compared to large companies

(Xie et al., 2010). Also, in innovation activities, SMEs should deal with a complicated implementation of these ideas into their management systems (Zeng et al., 2010; O'Regan et al., 2006). Some authors (Madrid-Guijarro et al., 2009) determined specific barriers hindering innovation activities mostly in SMEs due to their specific characteristics such as "limitations regarding external clients, existence of excessive control, lack of planning for changes demanded by the market and business environment, an inadequate education and lack of executives training" (Hussinger, 2010, p. 59). 
Each barrier to innovation is directly relevant to government policy-making. Some barriers are created by actions of governments themselves, ranging from the regulatory standards to the rules that are imposed on educational institutions, to antitrust policy. Others are associated with externalities that are often said to lead to market failure - externalities associated with knowledge creation or with labor markets. Governments adopt policies in each of these areas in attempt to fill the void that may be left by the imperfect operation of markets (Baldwin \& Gellatly, 2003).

\section{METHODOLOGY}

In order to examine the barriers to innovation activities of SMEs in Slovakia, as well as to present the past and present state of government's tools aimed at supporting innovation and removing barriers, we used secondary and primary data. The secondary data came from different European and domestic sources.

The Slovak Innovation and Energy Agency (SIEA) performed an empirical research with the main aim to identify the company needs in the potential development of their innovation activities. The research was conducted on the sample of 195 innovative companies chosen from the SIEA database. The data were collected via the questionnaire in November 2012 with the 29.2 $\%$ rate of return. Majority of the sample was formed of the micro enterprises (35.7\%), but also small enterprises $(23.2 \%)$, medium-sized enterprises (23.2\%) and large companies (17.9\%) participated in the research. The research focused mostly on the selected parameters of the innovation processes in the Slovak companies and on the barriers of their development. Moreover, it examined the state activities that may encourage to reinforce the innovation activities.

According to the documentary analysis of current literature and existing research, there has been no evidence of such a large research of barriers to innovations among SMEs in Slovakia since 2012. Therefore, we decided to perform a survey oriented on this topic in 2014 and for the purpose of identification of possible changes also in 2017.

The primary data were collected via a questionnaire in 2014 and again in 2017. In 2014, we asked 1,020 randomly selected SMEs in the Slovak Republic. We reached a $14.5 \%$ rate of questionnaires return, which means 144 respondents. From total number of respondents, micro enterprises were represented by $67 \%$, small enterprises by $25 \%$ and medium-sized enterprises by 8 $\%$. In 2017, we repeated the survey on the sample of 201 SMEs in the Slovak Republic. $71 \%$ of respondents were micro enterprises, $21 \%$ small enterprises and $8 \%$ medium-sized enterprises. The selection was again random with no accent to respondents' industry or region relations. According to the Fisher's Exact Test, both samples of SMEs were not representative according to the size classes of respondents. Based on the results of the 2014 questionnaire survey, we used slightly modified response options for the 2017 survey. Some barriers were omitted due to their low significance and we added some new barriers. In 2017, we focused specifically on the evaluation of the perceived quality of innovation policy in Slovakia.

We used methods of analysis, comparison, deduction, as well as mathematical methods for processing of the data collected. To answer the research questions, we used the non-parametric Friedman's test of variance analysis by ranks and the McNemar's test to check the marginal homogeneity of paired data. 
In order to achieve the goal of the paper, we set out the following research questions:

- Is there a difference between the size of the business and the barriers to innovations that businesses consider to be the most significant?

- Was there a change in perception of barriers by SMEs in Slovakia between 2014 and 2017?

\section{RESULTS AND DISCUSSION}

\subsection{Brief history of innovation policies in Slovakia}

In order to present the past and current barriers to innovation activities of SMEs in Slovakia, we consider it necessary to briefly present the main milestones of the development of innovation strategies and policies in Slovakia. It is the government that represents the decisive player in the business environment, which could greatly contribute, by the extent and timing of the measures, to the improvement or, on the contrary, the deterioration of the conditions for implementation of innovations in the economy.

In the long-term period, the European Union is planning the growth and development of the EU Member States and Europe as a whole, based on sustainability, job creation and, above all, on the active use of $\mathrm{R} \& \mathrm{D}$ in the form of innovation in all areas of human activity. The development of innovation activities in the EU Member States is anchored in EU strategy papers. The EU supports the achievement of objectives through a set of instruments and measures (financial and non-financial) that the EU distributes to the Member States.

Since 2004, the Slovak Republic, as an EU Member State, actively participated in preparation of the Lisbon Strategy. Slovakia presented its own "National Lisbon Strategy" under the title "Competitiveness Strategy of the Slovak Republic till the year 2010".

Before the current programming period (2014 - 2020), there was introduced the Innovation strategy for the years 2007 - 2013. The strategy was decomposed into the Innovation policy for the years 2008 - 2010 and later the Innovation policy for the years 2011 - 2013.

The Slovak Government prepared twelve tools to achieve objectives set in the Innovation policy 2008 - 2010. Unfortunately, the limited financial resources caused only the partial success of government tools. Three measures - building of regional innovation centers, innovation vouchers and support of projects in FP Competitiveness and Innovations were not implemented/due to the lack of funds. The main source of financing successfully implemented tools were the EU funds.

The following Innovation policy for the years 2011 - 2013 included thirteen tools (Innovation policy of the Slovak Republic for the years 2011 - 2013). The six of them were continuing from previous planning period (e.g. lifelong learning, support of structural funds, competition based on the most innovative act, protection of intellectual property, support for innovations from public sources, innovation vouchers). The new tools were oriented on the support of clusters, promotion of innovations, education of SMEs in innovations, secondary vocational education and support of innovation activities in SMEs. 
The main financial source for tools were again the European structural funds. Out of thirteen tools for the years $2011-2013$, only ten were implemented. The reason for not applying others was again the lack of financial resources. Some tools (Innovation vouchers, Support of innovative clusters) were used just before the end of the planned time period, some were used only once (Education for SMEs about innovations).

The above mentioned tools were implemented by five different government's agencies, which showed various problems in doing so. Since 2012, the Slovak Innovation and Energy Agency (SIEA) and the Slovak Tourism Agency have become the only two implementing agencies of the innovation policy tools.

The Slovak Government announced the RIS 3 - Research and Innovation Strategy for Smart Specialization of the Slovak Republic for the years 2014 - 2020 in 2013. The main goal is "to stimulate a structural change in the Slovak economy towards a growth based on increasing innovation ability and excellence in research and innovation in order to support sustainable growth of incomes, employment and quality of life." (RIS 3, 2014, p. 5).

RIS 3 critically evaluates the government's management of innovations before 2013 and sets four strategic objectives (RIS 3, 2014) in the area of added value growth in key industries, growth of research participation, innovative society and quality of human resources.

The RIS 3 objectives should be reached by 2020 by using 20 different tools. After four years of the RIS 3 declaration, there were implemented only few tools encouraging enterprises to enhance their innovations and tie them up to research institutions and universities. Till now, there has not been published any monitoring report on the RIS 3 goals fulfilment, therefore it is not possible to evaluate the success rate of this strategy. However, some positive results could be observed in the quality of business environment focusing on innovation support.

We can conclude that the research and innovation policies have always been a matter of central government institutions in Slovakia. The self - governing regions had neither power nor autonomy in supporting the innovations at regional level. The first regional innovation policies emerged only after 2007 , and they were only the measures for engaging the self-governments in EU structural funds in the period 2007 - 2013.

Since Slovakia has become the member of the European Union, we can observe a gradual transformation of the Slovak's support system for innovations. The division of powers and responsibilities of ministries and agencies is approaching the model used by the innovation leading EU countries. On the other hand, the Slovak's support system for innovations is strongly dependent on EU funds.

\subsection{Barriers to innovations of the Slovak companies (research performed by SIEA)}

Based on the assumption that barriers significantly influence innovation activities of the companies, part of the questionnaire research performed by SIEA was oriented on the identification of the most important barriers for Slovak innovative companies. The respondents could mark the importance of the predefined barriers to innovations with the grade 1 - 5 (1 for not important, 5 for critical importance). The overall results confirmed that $25.5 \%$ of the respondents considered the barriers as important and $10.5 \%$ as critically important. Among the barriers that influence 
the company innovations in the most significant way, there were included the lack of necessary resources inside the company and high costs of innovations. Important factors were also the uncertain demand for new products and services, the lack of external resources, qualified employees on the market and suitable innovation partners. On the other hand, respondents considered lack of information about the markets and lack of own qualified employees as not so significant barriers. The following figure compares the results according to the size of the company.

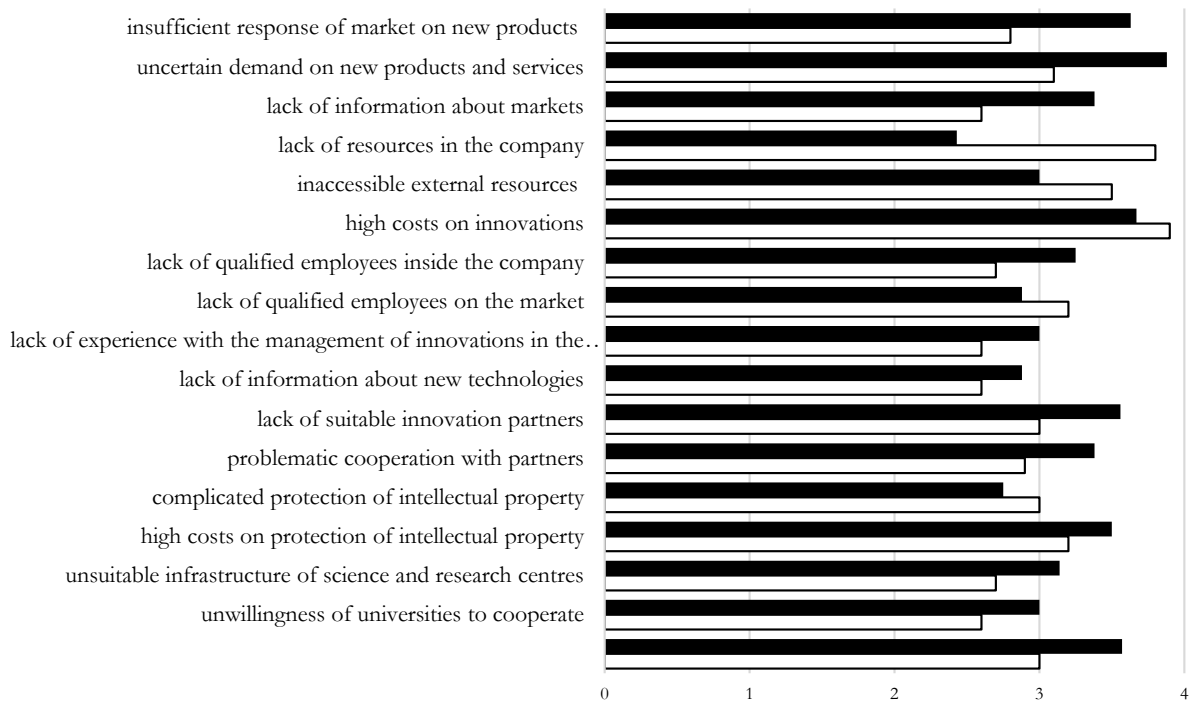

large companies $\square$ small companies

Fig. 3 - Barriers to innovation according to the research by SIE A. Source: Balog et al. 2013

Large companies considered as the most important barriers an uncertain demand for new products and services (3.88), high costs of innovations (3.67), insufficient response of the market on new products or services (3.63), dysfunctional transfer of technologies from the science and research institutions (3.57) and lack of suitable innovation partners (3.56). However, according to the results, it seems that they do not have to struggle with the lack of resources inside the company (2.43) as small enterprises (3.8). The identification of the most significant barriers to innovation on the sample of small companies (together with medium-sized enterprises) slightly differed from the previous group. The most problematic factors for these companies were, except the lack of company resources (mentioned above), high costs of innovations (3.9) together with the lack of external resources (3.5). Barriers with the lowest significance were the lack of information about new technologies (2.6), unwillingness of universities to cooperate (2.6) and lack of experience with the management of innovations. The differences between small and large companies were overall not so significant, only one factor was evaluated with a high importance on the side of large companies and a low importance on the side of small companies - lack of 
information about the markets. It seems that this is a result of orientation of large companies on the foreign and global markets that can increase the risk of their activities. On the other hand, the research has confirmed a different perception of barriers to innovation based on the region where the company operates. Companies located in the developed regions of Slovakia (e.g. Bratislava, Trnava) did not perceive the barriers to innovation activities so significantly compared to other companies located in less developed regions (e.g. Banská Bystrica or Prešov).

\subsection{Research on barriers to innovations in Slovak SMEs}

To study the change in perception of innovation barriers among SMEs in Slovakia, we have done two independent questionnaire surveys. The first one in 2014 and the second one in 2017. The timing of the surveys corresponds with the beginning and half time of current EU programming period and duration of RIS 3 strategy in Slovakia.

Table 6 presents the respondents' breakdown by their size. The respondents could identify multiple barriers in their responses, thus the sum of answers exceeds $100 \%$.

Tab. 6 - Barriers to innovation activities among Slovak SMEs in 2014. Source: own research

\begin{tabular}{|l|c|c|c|}
\hline \multirow{2}{*}{ Barriers } & \multicolumn{3}{|c|}{ Respondents } \\
\cline { 2 - 4 } & $\begin{array}{c}\text { micro } \\
\text { enterprises }\end{array}$ & $\begin{array}{c}\text { small } \\
\text { enterprises }\end{array}$ & $\begin{array}{c}\text { medium } \\
\text { enterprises }\end{array}$ \\
\hline lack of financial resources & $60.78 \%$ & $58.33 \%$ & $58.14 \%$ \\
\hline high costs of innovations & $41.18 \%$ & $41.67 \%$ & $86.05 \%$ \\
\hline lack of qualified employees & $33.33 \%$ & $50.00 \%$ & $39.53 \%$ \\
\hline lack of information & $17.65 \%$ & $18.75 \%$ & $30.23 \%$ \\
\hline lack of time for changes & $27.45 \%$ & $20.83 \%$ & $39.53 \%$ \\
\hline $\begin{array}{l}\text { uncertain demand for innovated products or } \\
\text { services }\end{array}$ & $54.90 \%$ & $45.83 \%$ & $55.81 \%$ \\
\hline $\begin{array}{l}\text { insufficient cooperation of state, universities } \\
\text { and enterprises }\end{array}$ & $47.06 \%$ & $47.92 \%$ & $44.19 \%$ \\
\hline unsuitable state innovation policy & $52.94 \%$ & $56.25 \%$ & $55.81 \%$ \\
\hline
\end{tabular}

The lack of financial resources was the most important barrier to innovations in micro and small enterprises, while in medium enterprises, it was the level of expected costs of innovations. Unsuitable state innovation policy was marked as the second most important barrier for micro and small enterprises, while for the medium enterprises, it was the third most important barrier. On contrary, ranking among the least influential barriers was the lack of information, a finding true for all categories of respondents.

Based on the results from 2014, we projected that also in 2017 the most important barrier limiting the innovation activities of micro and small enterprises would be insufficient amount of funding. Table 7 presents a detailed view on the identification of the innovation barriers according to the size of the enterprise. Again, the respondents could identify multiple barriers, which is why the sum of answers exceeds $100 \%$ in particular size groups of respondents. 
Tab. 7 - Barriers to innovation activities among Slovak SMEs in 2017. Source: own research

\begin{tabular}{|c|c|c|c|c|}
\hline \multirow[b]{2}{*}{ Barriers } & \multicolumn{3}{|c|}{ Respondents } & \multirow{2}{*}{$\begin{array}{c}\text { All respondents } \\
\text { Friedman's Mean } \\
\text { Rank / Place }\end{array}$} \\
\hline & $\begin{array}{c}\text { micro } \\
\text { enterprises }\end{array}$ & $\begin{array}{c}\text { small } \\
\text { enterprises }\end{array}$ & $\begin{array}{l}\text { medium } \\
\text { enterprises }\end{array}$ & \\
\hline lack of own resources & $59.85 \%$ & $46.34 \%$ & $41.17 \%$ & $7.13 / 1$ \\
\hline lack of external resources & $15.49 \%$ & $19.51 \%$ & $11.76 \%$ & $5.15 / 7$ \\
\hline high costs of innovation & $38.73 \%$ & $48.78 \%$ & $47.05 \%$ & $6.43 / 2$ \\
\hline lack of qualified employees & $22.53 \%$ & $48.78 \%$ & $52.94 \%$ & $5.88 / 3$ \\
\hline $\begin{array}{l}\text { lack of information about } \\
\text { technologies }\end{array}$ & $7.74 \%$ & $9.75 \%$ & $11.76 \%$ & $4.78 / 9$ \\
\hline $\begin{array}{l}\text { lack of information about } \\
\text { markets }\end{array}$ & $6.33 \%$ & $0.00 \%$ & $5.88 \%$ & $4.60 / 10$ \\
\hline $\begin{array}{l}\text { lack of suitable partners for in- } \\
\text { novation }\end{array}$ & $33.80 \%$ & $12.19 \%$ & $0.00 \%$ & $4.85 / 8$. \\
\hline $\begin{array}{l}\text { uncertain demand for innovated } \\
\text { products or services }\end{array}$ & $16.90 \%$ & $24.39 \%$ & $23.52 \%$ & $5.30 / 5$ \\
\hline $\begin{array}{l}\text { insufficient cooperation of state, } \\
\text { universities and enterprises }\end{array}$ & $17.60 \%$ & $17.07 \%$ & $35.29 \%$ & $5.30 / 5$ \\
\hline $\begin{array}{l}\text { unsuitable state innovation } \\
\text { policy }\end{array}$ & $25.35 \%$ & $14.63 \%$ & $47.05 \%$ & $5.60 / 4$ \\
\hline
\end{tabular}

The results have confirmed that there were some differences regarding the perception of innovation barriers among the respondents. Based on the results of Friedman's test ( $\mathrm{p}$ value $<0.000$ ), we reject the null hypothesis regarding the identical perception of innovation barriers. A ranking of the innovation barriers' significance according to the size of enterprises (McNemar's test), confirmed the following order of the most important barriers: the surveyed micro enterprises suffered the most from the lack of internal financial resources for innovations (59.86 \%), considered innovation costs too high $(38.73 \%)$, and the state innovation policy as unsupportive $(25.35$ $\%)$. The small enterprises, besides the lack of internal resources $(46.34 \%)$, indicated as two most important barriers the high costs of innovation (48.78 \%) and lack of qualified employees (48.78 $\%)$. Innovation activities among the medium enterprises were influenced mostly by the low level of employees with necessary qualifications (52.94\%), high costs of innovation (47.06 \%), and unsuitable state innovation policy $(47.06 \%$ ). The overall ranking of the barriers' significance, regardless of respondent size, is presented in the last column of Table 6 (Friedman's Mean Rank).

Comparing the results related to the main barriers to innovation activities of small and mediumsized enterprises in Slovakia, we can see that between the years 2014 and 2017 the following phenomena occurred:

- micro enterprises still considered as the most serious barrier the lack of internal financial resources, and a significant position among the barriers was related to the lack of potential partners for innovation co-operation. On the contrary, the importance of an uncertain demand for innovated products and services diminished; 
- in the group of small enterprises, the lack of own financial resources remained first as in 2014, while the importance of a barrier related to the lack of qualified employees for innovation activities persisted. The position of high innovation costs gained more significance, a factor which significantly weakened the barrier related to the unsuitability of the state innovation policy;

- in the group of medium enterprises, the number of respondents who marked the lack of own financial resources or high innovation costs as the barrier to their innovation activity decreased. Unlike the group of micro and small enterprises, in this size category unsuitable state innovation policy was considered to be the second most significant barrier.

- in spite of a weakening position of the unsuitable state innovation policy as a barrier to innovations among micro and small enterprises, the respondents in 2017 stated that the perceived quality of state innovation policy was very negative (more than $50 \%$ from micro and small enterprise, more than $60 \%$ form medium enterprises). These results are presented in Figure 4.

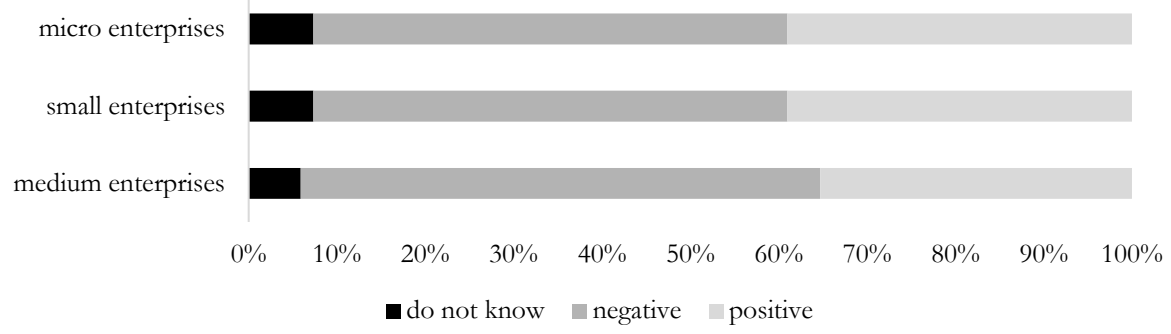

Fig. 4 - The perceived quality of state innovation policy in 2017. Source: own research

The innovation barrier in the form of lack of financial resources might be resolved through support programs created by the European Union and also by the Slovak Republic. However, there is still a low interest in these support programs among the micro and small enterprises due to the complexity of administration along with the time requirements from application to receiving of funds. Projects backed by EU funds are secured mainly by enterprises that ask for help from external consultancy institutions and have enough money to cover the project's expenditures till the moment funds are received. The need to ask an external consultancy institution for help when applying for EU funds lowers the transparency of the support system, thus there is a greater space for possible corruption.

The share of businesses, universities and private non-profit organizations' internal expenditures on innovation in Slovakia is relatively low, with public and EU sources prevailing. The Slovak innovation support system is oriented primarily on the supply side. The demand for innovations through public procurement is very weak or even nonexistent. One exception to this finding is the computerization of the public management system, which was funded internally; generally, there have been some successful publicly-funded projects (electronic identity cards, central register of contracts), as well as unsuccessful ones (eHealth, Tax Information System). 
Enterprises in Slovakia are facing serious barriers connected with migration of highly qualified employees to regions and industries with higher average wages. Although the average wage in Slovakia has been growing (during last 10 years by $62 \%$ ) and at present, we can observe the return of employees from abroad to Slovakia, there is still the lack of highly qualified employees.

The Slovak Government has introduced several tools to support the cooperation between businesses and academics/researchers. In 2015, a law was approved which introduced tax relief for $\mathrm{R} \& \mathrm{D}$ performers. This is considered to be an indirect tool of the Slovak Government to motivate enterprises to invest more sources in research and innovation (since 2018, the enterprises have been able to declare $100 \%$ more of incremental R\&D expenditures on their tax returns, but they must be investing in $\mathrm{R} \& \mathrm{D}$ on regular basis). Research institutions and universities are directed to cooperate with enterprises through the rules of their funding. On the other hand, the system of financing is perceived as insufficient, as it does not motivate these research entities to cooperate with enterprises.

Some barriers to innovation perceived by Slovak enterprises may be eliminated within the next years through a new strategic document. The Ministry of Economy of the Slovak Republic has published a proposal called Slovakia's Economic Policy Strategy 2030 which was approved by the government in 2018. This strategy also plots the long-term direction of economic policy through the identification of key tactical areas together with planned goals, activities along with their monitoring and measurement. Technological changes and support of the innovative potential of the Slovak Republic have been identified among the key targets of development for the Slovak economy. The main aim here is to create and stimulate an innovative economy with the assumption of implementing modern manufacturing processes. The strategy defines altogether eleven measures, albeit the formulation of these areas is mostly general (e.g. to support the effective connection of the academic and private sector in research activities, together with the effective implementation of innovations into practice; to reevaluate the effectiveness of investment aid with the emphasis on increasing added value and technological development; to remove administrative barriers regarding the utilization of public sources, mostly EU funds, for support of research, development and innovation, etc.). From this point of view, it is more important to focus on the content of the four action plans that will be progressively issued till 2030; these plans will elaborate on the measures in more detail.

Foreign studies suggest that the success of innovation policies and measures is highly contextspecific and dependent on past development. This means that the imitation of certain actions or components which worked in other countries may not produce the same expected results in the country that mimics them. Success in application is strongly influenced by seemingly trivial factors arising during implementation, while elements based on the past also play an important role.

\section{CONCLUSION}

The goal of the article was to critically evaluate the tools of the Slovak innovation strategies/policies as the background for the innovations performed by small and medium-sized enterprises. 
We have identified the most important barriers that hindered the innovation activities of Slovak SMEs in 2014, and consequently in 2017. A detailed analysis of the barriers has confirmed that particular size categories of respondents have to deal with innovation barriers within different frameworks. We have also observed that there was a change in the importance of barriers, i.e. some have increased, and others have decreased in importance over the years 2014 - 2017. The majority of respondents have considered the tools of RIS 3 (the current innovation strategy) as unsupportive toward their innovation activities. Although progress has been made in terms of transforming the Slovak support system for innovation into a standard European model, there still remain several weaknesses which create barriers to the innovation performance of Slovak enterprises. In particular, the respondents indicated the intensive administrative burden for enterprises participating in programs funded by the EU, along with the lack of public procurement for innovations.

\section{References}

1. Baldwin, J., \& Gellatly, G. (2003). Innovation Strategies and Performance in Small Firms. Cheltenham: Edward Elgar Publishing Limited. https://doi.org/10.4337/97817 81009703

2. Balog, M. et al. (2013). Inovativne Slovensko - východiská a výzvy (Analyses and studies of SIEA). Bratislava: Slovak Innovation and Energy Agency.

3. Beranová, M., Tabas, J., \& Vavřina, J. (2015). Key Aspects of Competitiveness: Focus on European Small and Medium-Sized Enterprises. In P. Huber, D. Nerudová, P. Rozmahel (Eds.), Competitiveness, Social Inclusion and Sustainability in a Diverse European Union: Perspectives from Old and New Member States. (121-144). Switzerland: Springer International Publishing. https://doi.org/10.1007/978-3-319-17299-6

4. Cainelli, G., Evangelista, R., \& Savona, M. (2006). Innovation and economic performance in services: a firm-level analysis. Cambridge Journal of Economic, 30 (3), 435-458. https://doi. org/10.1093/cje/bei067

5. Ceccagnoli, M. (2009). Appropriability, pre-emption, and firm performance. Strategic Management Journal, 30 (1), 81-98. https://doi.org/10.1002/smj.723

6. Czech Statistical Office. (2018). Inovační aktivity podniků - 2014-2016. Retrieved June 15, 2018, from https://www.czso.cz/csu/czso/inovacni-aktivity-podniku-2014-2016

7. Demirbas, D., Hussain, J. G., \& Matlay, H. (2011). Owner managers' perceptions of barriers to innovation: empirical evidence from Turkish SMEs. Journal of Small Business and Enterprise Development, 18 (4), 764-780. https://doi.org/10.1108/1462600111 1179794

8. Duarte, F., Madeira, M. J., Moura, D. C., Carvalho, J., \& Moreira, J. R. M. (2017). Barriers to innovation activities as determinants of ongoing activities or abandoned. International Journal of Innovation Science, 9 (3), 244-264. https://doi.org/10.1108/IJIS-01-2017-0006

9. D’Este, P., Iammarino, S., Savona, M. \& Tunzelmann, N. V. (2012). What hampers innovation? Revealed barriers versus deterring barriers. Research Policy, 41 (2), 482-488. https://doi.org/10.1016/j.respol.2011.09.008

10. Einsiedler, I. (2013). Embedded Systeme für Industrie 4.0. Production Management, 18 (1), $26-28$. 
11. European Commission. (2016). Innobarometer 2016 - EU business innovation trends. Retrieved April 15, 2018, from http://ec.europa.eu/growth/industry/innovation/factsfigures/innobarometer_en

12. Eurostat. (2018). General information on the enterprises by NACE Rev. 2 activity and size class. Retrieved July 9, 2018, from http://appsso.eurostat.ec.europa.eu/ nui/show. do?dataset=inn_cis9_noin\&lang=en.

13. Hadjimanolis, A. (2003). The barriers approach to innovation. In L. V. Shavinina (Ed.), The international handbook on innovation. (559-573). Oxford: Elsevier Science.

14. Hölzl, W., \& Janger, J. (2014). Distance to the frontier and the perception of innovation barriers across European countries. Research Policy, 43 (4), 707-725. https://doi.org/10.1016/ j.respol.2013.10.001

15. Hueske, A. K., Endrikat, J., \& Guenther, E. (2015). External environment, the innovating organization, and its individuals: a multilevel model for identifying innovation barriers accounting for social uncertainties. Journal of Engineering and Technology Management, 35 (1), 45-70. https://doi.org/10.1016/j.jengtecman.2014. 10.001

16. Hunady, J., Pisar, P., Musa, H., \& Musova, Z. (2017). Innovation support and economic development at the regional level: panel data evidence from Visegrad countries. Journal of International Studies, 10 (3), 147-160. https://doi.org/ 10.14254/2071-8330.2017 /10-3/11

17. Hussinger, K. (2010). On the importance of technological relatedness: SMEs versus large acquisition targets. Technovation, 30 (1), 57-64. https://doi.org/10.1016/ j.technovation. 2009.07.006

18. Government Office of the SR (2018). Innovation policy of the SR for the years 2011-2013. Retrieved July 12, 2018, from http://www.rokovania.sk/Rokovanie.aspx/BodRokovaniaDe tail?idMaterial $=1961$.

19. Keizer, J., Halman, J., \& Song, M. (2002). From experience: applying the risk diagnosis methodology. Journal of Product Innovation Management, 19 (3), 213-232. https://doi. org/10.1111/1540-5885.1930213

20. Madrid-Guijarro, A., Garcia, D., \& Van Auken, H. (2009). Barriers to innovation among Spanish manufacturing SMEs. Journal of Small Business Management, 47 (4), 465-488. https:// doi.org/10.1111/j.1540-627X.2009.00279.x

21. Mosey, S., Clare, J., \& Woodcock, D. (2002). Innovation decision making in British manufacturing SMEs. Integrated Manufacturing Systems, 13 (3), 176-183. https://doi.org/10.110 8/09576060210416625

22. O'Regan, N., Ghobadian, A., \& Sims, M. (2006). Fast tracking innovation in manufacturing SMEs. Technovation, 26 (2), 251-261. https://doi.org/10.1016/ j.technovation .2005 .01 .003

23. RIS 3 - Research and Innovation Strategy for Smart Specialization of the Slovak Republic for 2014 - 2020. Retrieved February 10, 2018, from https://rio.jrc.ec.europa.eu/en/library/ strategy-smart-specialisation-slovak-republic-ris3 
24. Rodríguez-Pose, A., Cataldo M., \& Rainoldi, A. (2014). The Role of Government Institutions for Smart Specialization and Regional Development (JRC Technical Report No. 04/2014). Luxembourg: Publications Office of the European Union. https://doi.org $/ 10.2791 / 71842$

25. Sieradzka, K. (2014). Barriers to Innovation Activity of Polish Small and Medium-sized Enterprises. Przedsiębiorstwo i Region, 6 (1), 88-96.

26. Statistical office of the SR. (2018). The share of innovative enterprises in Slovakia. Retrieved July 9, 2018, from http://datacube.statistics.sk

27. Urbancová, H. (2013). Competitive Advantage Achievement through Innovation and Knowledge. Journal of Competitiveness, 5 (1), 82-96. https://doi.org/10.7441/ joc.2013.01.06

28. Xie, X. M., Zeng, S. X., \& Tam, C. M. (2010). Overcoming barriers to innovation in SMEs in China: a perspective based cooperation network. Innovation: Organization and Management, 12 (3), 298-310. https://doi.org/10.5172/impp.12.3.298

29. Zastempowski M., \& Przybylska N. (2016). Cooperation in Creating Innovation in Polish Small and Medium-Sized Enterprises in the Light of Empirical Studies. Journal of Competitiveness, 8 (2), 42-58. https://doi.org/10.7441/joc.2016.02.04

30. Zeng, S. X., Xie, X. M., \& Tam, C. M. (2010). Relationship between cooperation networks and innovation performance of SMEs. Technovation, 30 (3), 181-194. https://doi. org/10.1016/j.technovation.2009.08.003

\section{Contact information}

Ing. Lenka Hvolkova, PhD.

Matej Bel University Banská Bystrica

Faculty of Economics

Slovak Republic

E-mail:lenka.hvolkova@umb.sk

ORCID: 0000-0002-9201-0577

Ing. Ladislav Klement, PhD.

Matej Bel University Banská Bystrica

Faculty of Economics

Slovak Republic

E-mail: ladislav.klement@umb.sk

ORCID: 0000-0003-0436-4664

Ing. Vladimira Klementova, PhD.

Matej Bel University Banská Bystrica

Faculty of Economics

Slovak Republic

E-mail:vladimira.klementova@umb.sk

ORCID: 0000-0002-4551-0448
Ing. Marcela Kovalova, PbD.

Matej Bel University Banská Bystrica

Faculty of Economics

Slovak Republic

E-mail:marcela.kovalova@gmail.com

ORCID: 0000-0002-5027-2704 